DOI: $10.19195 / 0524-4544.322 .11$

\author{
WITOLD MAŁECKI
}

Uniwersytet Wrocławski

\title{
Sprawozdanie z Międzynarodowej Letniej Szkoły Prawa „Prawna regulacja działalności turystycznej — rosyjskie tendencje i zagraniczna specyfika", Soczi, 31 lipca-11 sierpnia 2016 r.
}

Rosnący stopień specjalizacji regulacji prawnych odnoszonych do poszczególnych sfer dynamicznie ewoluującego życia społeczno-gospodarczego nierozerwalnie wiąże się z potrzebą kreowania autonomicznych instrumentów prawnych, przyjmujących konstrukcję służebną wobec specyficznie kształtujących się uwarunkowań i kierunków rozwoju danej sfery życia. Uwarunkowania i kierunki te, odmienne w odniesieniu do poszczególnych państw, determinują swoistości w prawnej treści i formie instrumentów prawnych ingerencji państwa $\mathrm{w}$ sfery życia społeczno-gospodarczego, ich spójność w obrębie danej sfery oraz stopień autonomizacji na tle ogólnych konstrukcji systemu prawa. Próba prawnoporównawczej refleksji nad unormowaniami szeregu ustawodawstw w dynamicznie rozwijającym się sektorze turystyki stała się motywem przewodnim Międzynarodowej Letniej Szkoły Prawa pod tytułem „Prawna regulacja działalności turystycznej - rosyjskie tendencje i zagraniczna specyfika”, odbywającej się w dniach 31 lipca-11 sierpnia 2016 r. w filii Wszechrosyjskiego Państwowego Uniwersytetu Sprawiedliwości w Soczi. W Szkole wzięły udział delegacje sześciu uniwersytetów - uniwersytetu-gospodarza, Uniwersytetu Nebrija w Madrycie (Hiszpania), Uniwersytetu Insubrii w Como (Włochy), Mińskiego Państwowego Uniwersytetu Lingwistyczego (Białoruś), Rosyjsko-Armeńskiego Uniwersytetu Słowiańskiego w Erewaniu (Armenia) oraz Uniwersytetu Wrocławskiego. 
Podczas wystąpień i obrad w ramach Szkoły podejmowano zarówno teoretyczne, jak i praktyczne problemy funkcjonowania regulacji prawnych w sferze turystyki. Kwestiom teoretycznym poświęcone były m.in. referaty prof. E.W. Dutkowskiego (Wszechrosyjski Państwowy Uniwersytet Sprawiedliwości) Założenia prawnej regulacji działalności turystycznej w Rosji oraz mgr. W. Małeckiego (Uniwersytet Wrocławski) Cele prawnej regulacji w dziedzinie działalności turystycznej - doświadczenia międzynarodowe. W referatach oraz podczas dyskusji rozważano zagadnienia m.in. zasadności wydzielania w systemie prawa zbioru norm, nazywanego ,prawem turystycznym”, postrzegania prawa turystycznego w perspektywie publicznoprawnej i prywatnoprawnej, trafności sytuowania go w obrębie prawa gospodarczego, a także stopnia i kierunków normatywnej ingerencji państwa w sferę działalności turystycznej.

Uczestnictwo licznych delegacji zagranicznych pozwoliło poddać wszechstronnej analizie kwestie odrębności w kształtowaniu się prawa turystycznego w krajach Europy Zachodniej i dawnych państwach socjalistycznych, a także charakter prawny międzynarodowego prawa turystycznego i jego oddziaływania na ustawodawstwa krajowe. W referatach m.in. prof. J. Manso Vergary (Uniwerystet Nebrija) Specyfika prawnej regulacji działalności turystycznej w Hiszpanii i prof. E.W. Dutkowskiego Tendencje rozwojowe prawnej regulacji działalności turystycznej $w$ Rosji poruszono problemy praktyczne, takie jak: katalog prawnych instrumentów ochrony konsumenta na rynku usług turystycznych, status prawny przedsiębiorców świadczących usługi turystyczne oraz wpływ zagrożeń o charakterze terrorystycznym na kształt ustawodawstwa dotyczącego działalności turystycznej. W związku z udziałem delegacji z trzech państw członkowskich Unii Europejskiej w toku obrad analizowano zagadnienia prawa unijnego, w szczególności różnice w założeniach ogólnych i rozwiązaniach szczegółowych odnośnie do dyrektywy Rady nr 90/314/EWG z dnia 13 czerwca 1990 r. w sprawie zorganizowanych podróży, wakacji i wycieczek oraz zastępującej ją dyrektywy Parlamentu Europejskiego i Rady nr 2015/2302 z dnia 25 listopada 2015 r. w sprawie imprez turystycznych i powiązanych usług turystycznych.

Rozważania nad prawną regulacją działalności turystycznej zostały uzupełnione odniesieniami do społeczno-ekonomicznego kontekstu kreującego ramy rozwoju turystyki, czemu poświęcone zostały referaty prof. A.W. Apuchtina (Wszechrosyjski Państwowy Uniwersytet Sprawiedliwości) Turystyka pokolenia ,Y" - nowe strategie i transformacje oraz Specyfika nowoczesnych technologii wykorzystywanych w branży hotelarskiej.

Uczestnikom Szkoły zapewniono bogaty program turystyczny, obejmujący m.in. wizyty na obiektach sportowych, na których odbywały się XXII Zimowe Igrzyska Olimpijskie w 2014 r., a także zwiedzanie głównych zabytków i muzeów Soczi. 
Międzynarodowa Letnia Szkoła Prawa z udziałem delegacji Uniwersytetu Wrocławskiego stanowiła kolejny etap współpracy między Uniwersytetem Wrocławskim i Wszechrosyjskim Państwowym Uniwersytetem Sprawiedliwości, prowadzonej w ramach programu „Erasmus Mundus”. Do wcześniejszych przedsięwzięć naukowych należały Polsko-Rosyjska Debata „Współczesne tendencje w polskim prawie", przeprowadzona w grudniu 2013 r. we Wrocławiu, oraz Międzynarodowa Letnia Szkoła Prawa „Prawnomiędzynarodowe i krajowe aspekty ochrony dóbr kultury”, zorganizowana w lipcu 2014 r. w Moskwie. We wspólnych przedsięwzięciach wzięło dotychczas udział około stu wykładowców oraz studentów z Polski i Rosji. 